\title{
ALCOHOL INTOXICATION AND ITS INFLUENCE ON THE COURSE OF MALE RATS SPERMATOGENESIS
}

\author{
NeLIA DOLYNKO, TETIANA MYKYTYN, NATALIA BIELOVA
}

\begin{abstract}
Morphometric and functional analysis of germ cells in histological micropreparations and ejaculate of male rats at the control group on the 7th, 14th, 21st and 28th days of alcoholization at experimental animals was performed. Prolonged use of ethanol has been shown to reduce resistance to spermatogenic epithelial cells, which are at different stages of development, manifested by inhibition of spermatogenesis with a decrease in sperm count and spermatids, and in ejaculate - a decrease in sperm concentration with increasing number of spermatozoa.
\end{abstract}

Keywords: spermatogenic epithelium, alcohol intoxication, resistance.

\section{INTRODUCTION}

The work is a fragment of the research topic at the Department of Human and Animal Anatomy and Physiology at Vasyl Stefanyk Precarpathian National University "Morphofunctional state of the tissue elements of the male gonad under the influence of pathogenic factors" (№ state registration 0105U009082).

The infertility problem at married couples has acquired social significance, because it is the lack of settlement at the demographic problem that affects the social security and future defense capabilities of any state. According to statistics, disorders of the reproductive system are observed by both women and men, which in the latter is about 45\% [2]. An important prerequisite for conceiving and giving birth to a healthy and full-fledged generation is the normal state of a man's reproductive system, because it is the sperm that determines the sex of the unborn child. Among the factors that contribute to the development of infertility are the main varicose veins of the spermatic cord, testicular trauma, urogenital infections, prostatitis, hypogonadism [3, 7]. In the future, this leads to a high risk of developing specific complications in such patients: infertility, hypogonadism, testicular cancer and erectile dysfunction.

In recent years, more and more work has been devoted to studying the influence of factors that cause a kind of endogenous intoxication of the cell, which for the latter serves as stress [11]. One such factor is alcohol intoxication, which is the result of high and concentrated doses of ethanol. The problem of alcohol consumption has already acquired social significance. According to the literature, alcohol consumption has a negative effect on various body systems $[5,6]$. 
In addition to the liver, which is the target organ for alcohol, the male reproductive system undergoes significant pathological changes. According to the literature, ethanol and its metabolites are strong toxins for germ cells of different stages of development [13], which leads to the manifestation of pathological changes in them, a decrease in sperm concentration in ejaculate and deterioration of their kinesisgram. A number of authors indicate the toxic effect of alcohol on lowering the level of the main androgenic hormone - testosterone, which regulates the course of spermatogenesis [4]. Prenatal administration of ethanol leads to morphological abnormalities of the testes, low testosterone levels and disruption of redox processes [12]. For the application of modern assisted reproductive technologies are important data on the structural and functional state, the nature of genetic material, in particular the integrity of sperm DNA, as the main indicator of the possibility of developing healthy offspring [8, 9].

The aim of this study was to investigate the resistance of spermatogenic epithelial and ejaculate cells to endogenous intoxication caused by the action of ethanol on days 7, 14, 21 and 28 of alcohol intoxication.

\section{MATERIALS AND METHODS OF RESEARCH}

The studies were performed on 44 male laboratory rats weighing 180-200 g. Animals were kept and manipulated in accordance with the General Ethical Principles of Animal Experiments approved by the 1st National Congress of Bioethics (2001). The animals were kept in proper conditions in the vivarium with optimal lighting and free access to food and water. The experimental animals were divided into 4 groups - 11 rats each.

The first, second and third groups received a dose of $30 \%$ ethanol at the rate of $0.2 \mathrm{ml}$ per $100 \mathrm{~g}$ of body weight of the animal for 7,14, 21 and 28 days. The fourth group, which received water for ethanol dilution, served as a control. From the experiment, the animals were removed by decapitation under general ether anesthesia. In micropreparations of the testis were determined: the diameter of the seminal vesicles in $\mu \mathrm{m}$, the degree of damage to spermatogenic epithelial cells in them - in $\%$, the number of spermatogenic epithelial cells that occur in stage VII of the cycle. The criterion for determining the degree of damage to the cells of the spermatogenic epithelium was the histological picture of tortuous seminal vesicles of one of the five types.

Determination of the number of spermatogenic epithelial cells in the tortuous seminal tubules of the testis was performed in stage VII of the cycle, which is the most optimal for counting and detecting their sample sensitivity. Images were obtained using a SIGETA M3CMOS 8500 camera. Morphometric analysis of histological structures was performed using Micro Captur software. Ejaculate was taken from the tail of the testis for further examination on days 7, 14, 21 and 28 after ethanol administration.

\section{RESEARCH RESULTS AND THEIR DISCUSSION}

According to morphometry in adult rats, testicular weight is $(1.408 \pm 0.40) \mathrm{mg}$ on average. The testicular parenchyma is composed of tortuous seminal tubules, which are tightly adjacent to each other (Fig. $1 \mathrm{a})$. Their diameter is $(241.12 \pm 2.31) \mu \mathrm{m}$, which are filled with adjacent concentric layers of germ cells of different stages of development: spermatogonia, primary and secondary spermatocytes, spermatids, and closer to the lumen of the tubules - sperm (Fig. 2 b). 


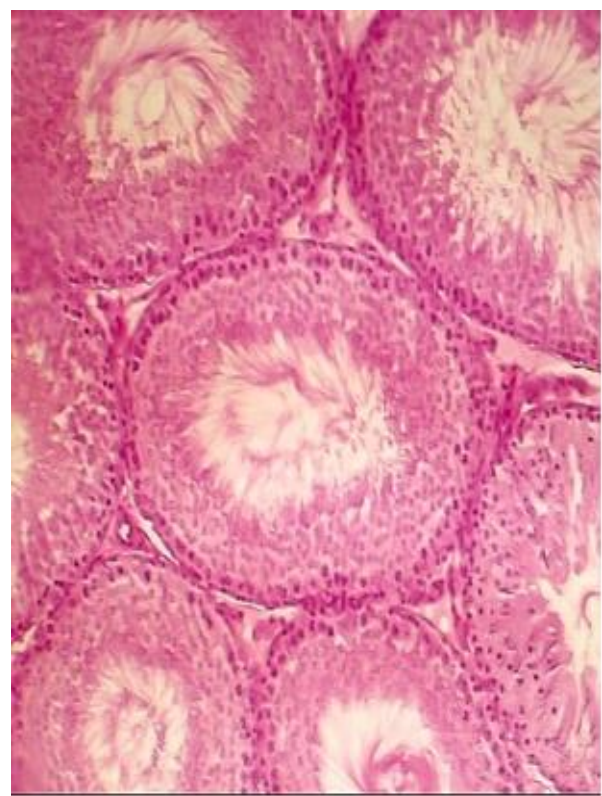

$a$

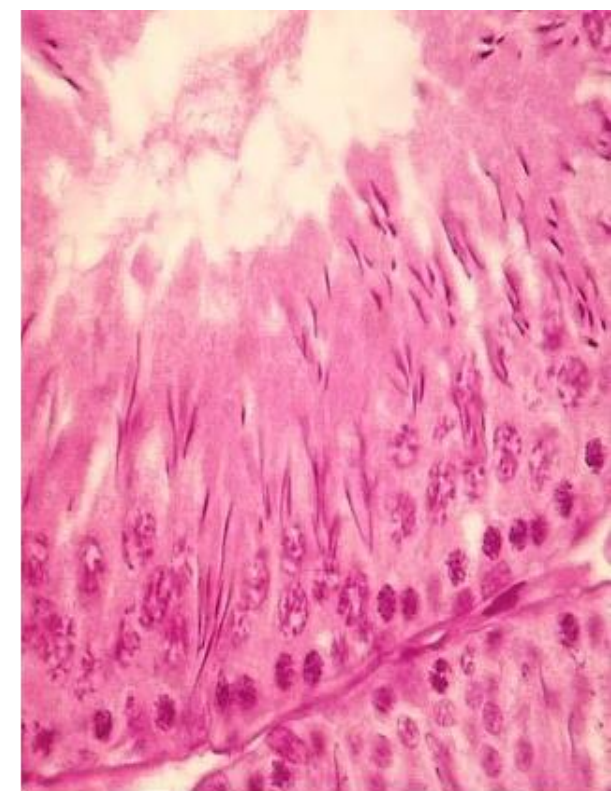

$b$

Fig. 1. The tortuous seminal tubules testis of the rat in the control group. Histological picture shows normal spermatogenesis with a layered arrangement of spermatogenic epithelial cells at all stages of development. Interstitial endocrinocytes are located between the convoluted seminal vesicles. Microphotography. Hematoxylin-eosin, (magnification $\times$

400.

In morphologically normal sperm there are: head with acrosomal area, neck, intermediate and main part of the flagellum. According to our observations, normally the head of a rat sperm, $2.5 \mu \mathrm{m}$ long (Fig. 2), has clear contours and resembles a hook. The head gradually turns intohomogeneous neck without abnormal thickenings and cytoplasmic drops. The flagellum has the form of a long axial thread, in which the intermediate and main parts are distinguished. Terminal inclusions in the flagella are not observed (see Fig.2).



Fig. 2. Sperm of laboratory rats of the control group. 1 - head; 2 - intermediate part of the flagellum; 3 - the main part of the flagellum. Microphotography. Eosin-nigrosine staining, magnification $\times 400$.

The parenchyma of the testes of rats intoxicated for 7 days is characterized by a reduction in the layers of spermatogenic epithelial cells. (Fig. 3.a) 
The diameter of the tortuous seminal tubules is, on average, $(230.36 \pm 4.78) \mu \mathrm{m} .80 \%$ of tortuous seminal vesicles retain their normal structure, $14 \%$ have a mild degree of damage, and $6 \%$ of tubules have a severe degree of damage. We did not find significant violations of the morphological and functional organization of sperm at this time of alcoholization.

The rats testis parenchyma, alcoholized for 14 days, is characterized by an increase in edema of the interstitial connective tissue (fig. $3 \mathrm{~b}$ ), which accumulates, adversely affects the main structural elements of the hematotesticular barrier.

There is a desquamation part of the cells of the spermatogenic epithelium, which lie freely in the lumen of the tubules. The average diameter of tortuous seminal vesicles decreases and is $(225.22 \pm 3.60)$ $\mu \mathrm{m}$. This period of alcoholization is characterized by a mild degree of damage to the tortuous seminal tubules, which is $26.3 \%, 6.5 \%$ of the tubules have a severe degree of damage, $67.2 \%$ of the tubules are characterized by a normal course of spermatogenesis.

We found that on the 14th day of the experiment the number of sperm decreased to $(64.70 \pm 1.5)$ million / $\mathrm{ml}$, against $(67.50 \pm 3.60)$ million / $\mathrm{ml}$ in the control group of animals.

On the 21st day of the experiment, the ratio of the number of tortuous seminal vesicles with varying degrees of damage to the spermatogenic epithelium changes.

The average diameter of the tortuous seminal vesicles is reduced to $221.17 \pm 2.44 \mu \mathrm{m}$. The number of tubules with a slight degree of damage to germ cells reaches $24.5 \%$, and with severe $-34.0 \% .10 .2 \%$ of devastated tubules were also found and only $31.3 \%$ of the tubules retain their normal structure.

In most of them there is a stratification of its own shell, the detachment of germ cells from it. There is a reduction of the layers of spermatogenic epithelium (fig. $3 \mathrm{c}$ ).

In the course of the experiment we found that increasing the term of alcoholization leads to a decrease in morphological and functional resistance germ cells on different stages of development to the action of ethanol, manifested by severe damage to tortuous seminal tubules, focal desquamation layers of spermatogenic epithelium . In many cases, there is a massive exfoliation at germ cells on different stages of differentiation into the lumen of the seminal vesicles and their subsequent devastation (Fig. 3.d).

Thus, in the long term alcoholism (28th day), the diameter of the seminal vesicles decreases to $(221.17 \pm 2.44)$ microns. The layer-by-layer arrangement in a spermatogenic epithelium characteristic at norm changes, giant multinucleated cells are formed. The ratio in the number of tubules with different degrees at cell damage changes. Tortuous seminal vesicles with a normal structure are $-28.3 \%$, with a slight degree of damage $-24.4 \%$, with a severe degree $-36.1 \%$, and devastated $11.2 \%$ of seminal vesicles. Here is a tendency to further reduce the number of sperm in the ejaculate at alcoholic animals.
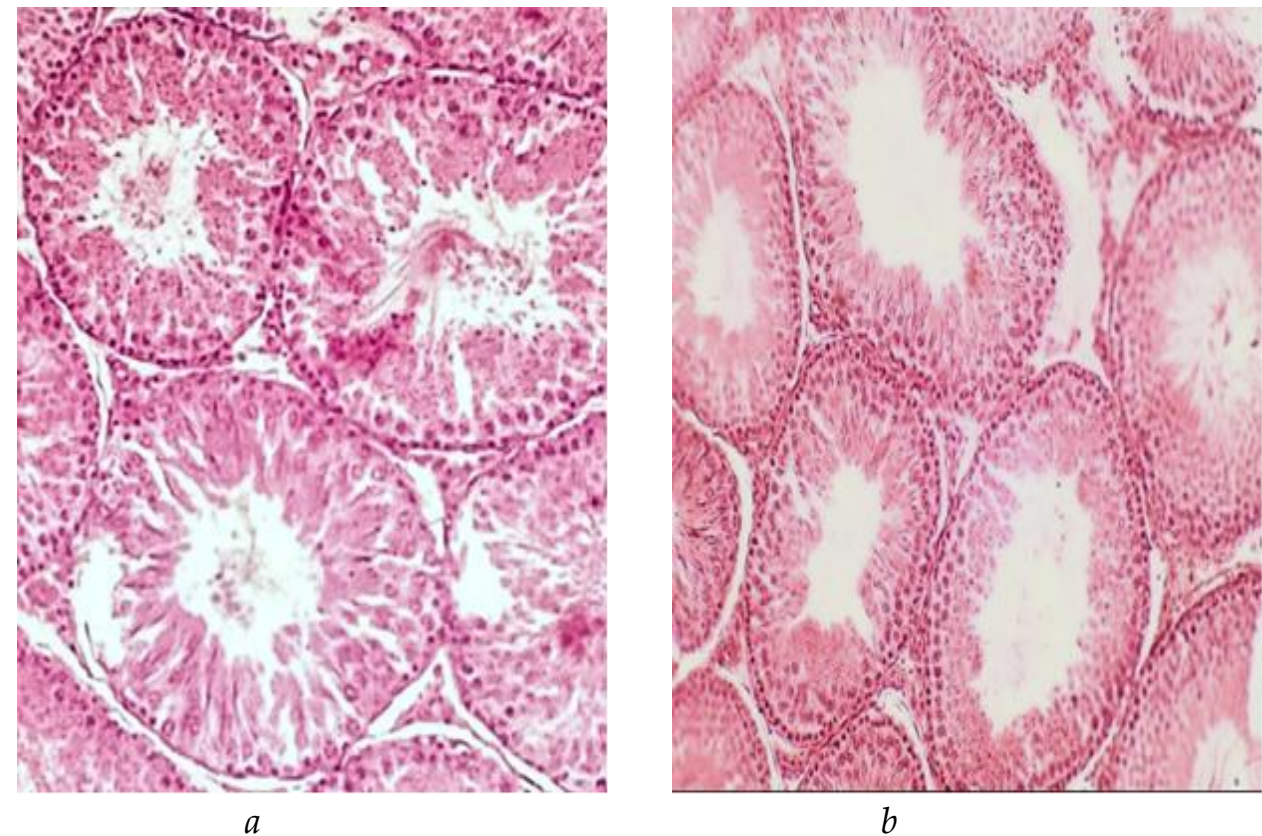

$b$ 


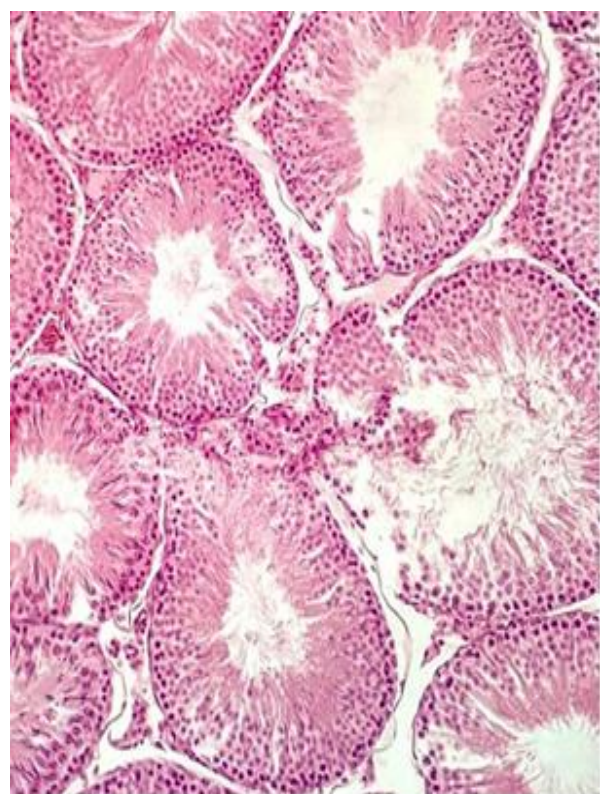

c

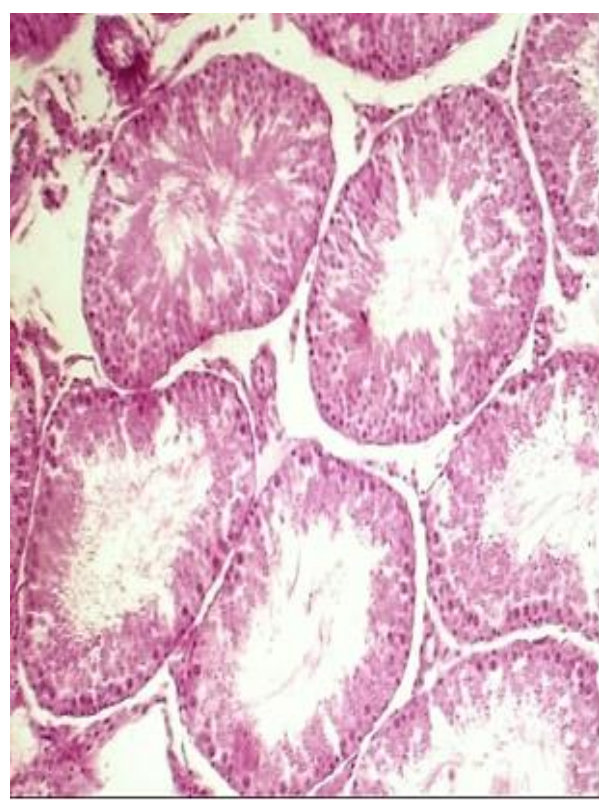

d

Fig. 3. Focal deformation of the layers of cells of the spermatogenic epithelium of the rat testis at different times of alcoholism. Histological picture is characterized by reduction of layers of spermatogenic epithelium (a), desquamation of germ cells into the lumen of the tortuous spermatic tube (b), disorganization of germ cells and their detachment from the basement membrane (c), massive exfoliation of spermatogenic epithelial cells in proboscis (d). Microphotography. Hematoxylin-eosin,

(magnification $\times 400$.

The concentration of sperm in the ejaculate decreases to $(56.20 \pm 2.30)$ abl / $\mathrm{ml}$ against $(67.50 \pm 3.60)$ $\mathrm{abl} / \mathrm{ml}$, the number of morphologically normal sperm - up to $57.70 \%$ against $75.52 \%$, the number of living sperm to $61.75 \%$ vs. $79.36 \%$, the number of sperm with progressive movement to $-35.31 \%$ vs. $55.62 \%$ in normal animals.We found significant structural changes in the sperm head, which are manifested by its vacuolation and amorphousness, indicating the absence or lysis of the acrosome. The contours of the sperm head are uneven, there is a division into fragments (Fig. 4) and amorphous structure.

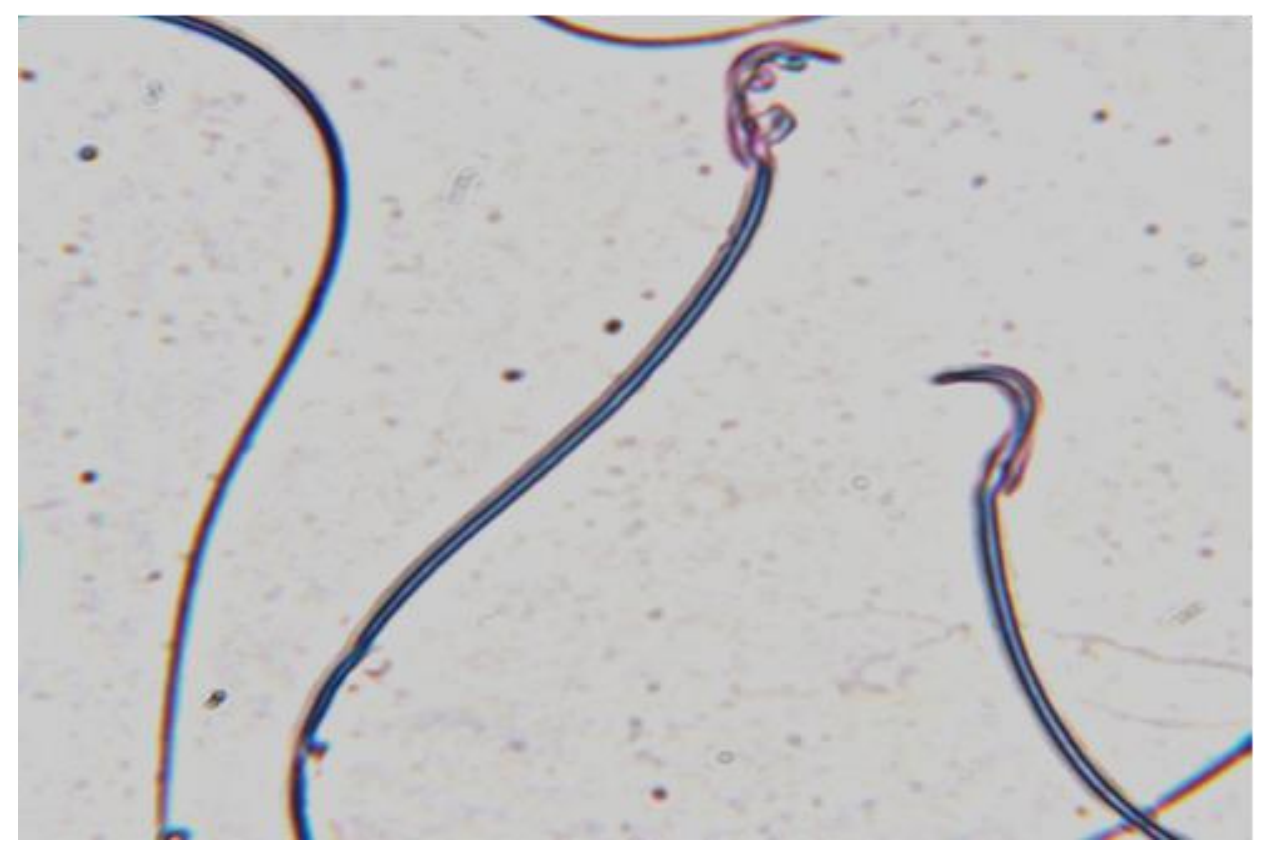

Fig. 4. Fragmentation of the rat sperm head in the long term alcoholism. Eosin-nigrosine staining, magnification $\times 400$. 
This period of the experiment is characterized by a significant level of sperm agglutination, significant deformation at the main and intermediate part of the flagella in sperm and their heterogeneity in structure along the entire length with a pronounced cytoplasmic excess, which adversely affects their motility. Prospects for further research. Our data on the morphological and functional resistance germ cells to the action of ethanol will serve as a model for the application of correction of spermatogenesis.

\section{CONCLUSION}

1. In the course of the experiment we showed that the resistance germ cells to the action of ethanol decreases with increasing duration of alcoholism.

2. It is established that in the long term of alcoholization there is a focal reduction of the layers at spermatogenic epithelium with a decrease in the number of germ cells at different stages of development.

3. In the long term of the experiment we found that on the part of sperm morphological changes are focal in nature, manifested by fragmentation at their heads and significant deformation of the flagella..

\section{REFERENCES}

[1] Bragina Y.Y. Spermiologic examination protocol. Andrology and Genital Surgery, 15 (1) (2014), 15-24.

[2] Hrytsulyak B.V., Hrytsulyak V.B., Lytvynets E.A., Kostenko L.V., Polyvkan M.I. Hemodynamic changes in the blood vessels of the spermatic cord and testis in oblique conditions inguinal hernia and after inguinal canal plastics. Clinical Anatomy and Operative Surgery, 14 (1) (2015), 45-48.

[3] Gotyur O.I. Structural and functional features of the testis and epidermis in men of reproductive age (22-35) years in the norm. Galician Medical Bulletin, 3 (2012), 24-26.

[4] Gladkova A.I. Andrological manifestations of stress. Kharkiv, 2013.

[5] Derecha L.M. The composition of phospholipids of blood cells, liver and brain of animals with prolonged exposure to ethanol. Bulletin of Kharkiv National University named after V.N. Karazina. Series: Biology, 5 (768) (2007), 25-28.

[6] Derecha L.M. Alcohol and its effect on the body: a review of the literature. Bulletin of Kharkiv National University named after V.N. Karazina. Series: Biology, 6 (788) (2007), 7-16.

[7] Pivtorak V.I., Smiyukha A.A. Morphology of Sertoli cells in experimental varicocele and after its treatment. Russian Medical and Biological Bulletin named after Academician I.P. Pavlova, 4 (2013), 17-23.

[8] Chornokulsky I.S. Criteria for assessing the potential of male fertility. Ukrainian Medical Journal, 4 (96) (2013), 154-158.

[9] Chornokulsky I.S., Tchaikovsky Y.B., Boyko M.I., Bazalytska S.V. Morphological features of male ejaculated sperm in normal and infertility. World of Medicine and Biology, 4 (42) (2013), 108-115.

[10] Hrytsulyak B.V. The nature of cytohistological changes in the testes of infertile men of mature age due to alcoholism. Bulletin of problems of biology and medicine, Issue 4, 1 (153) (2019), 221-223.

[11] Hrytsulyak B.V. Histostructural changes in the testes of mature men under conditions of chronic alcoholism. Proceedings of the scientific-practical conference "Applied aspects of the morphology of experimental and clinical research" October 10 - 11, 2019, Ternopil, 56-57.

[12] Pourmasumi S., Sabeti P., Rahiminia T., Mangoli E., Tabibnejad N., Talebi A.R. The etiologies of DNA abnormalities in male infertility: An assessment and review. Int J Reprod Biomed (Yazd), 15 (6) (2017), 331-344.

[13] Priya P.H., Girish B.P., Reddy P.S. Restraint stress exacerbates alcohol-induced reproductive toxicity in male rats. Alcohol, 48(8) (2014), 781-786. doi: 10.1016/j.alcohol.2014.07.014 
[14] Abarikwu S.O., Duru Q.C., Chinonso O.V., Njoku R.C. Antioxidant enzymes activity, lipid peroxidation, oxidative damage in the testis and epididymis, and steroidogenesis in rats after coexposure to atrazine and ethanol. Andrologia, 48 (5) (2016), 548-57. doi: 10.1111/and.12478

[15] Liu M., Zhang Q., Pei L., Zou Y., Chen G., Wang H. Corticosterone rather than ethanol epigenetic programmed testicular dysplasia caused by prenatal ethanol exposure in male offspring rats. Epigenetics, 14 (3) (2019), 245-259. doi: 10.1080/15592294.2019.1581595

[16] Horibe A., Eid N., Ito Y., Otsuki Y., Kondo Y. Ethanol-Induced Autophagy in Sertoli Cells Is Specifically Marked at Androgen-Dependent Stages of the Spermatogenic Cycle: Potential Mechanisms and Implications. Int J Mol Sci., 20 (1) (2019). doi: 10.3390/ijms20010184

Address: Nelia Dolynko, Tetiana Mykytyn, Natalia Bielova, Vasyl Stefanyk Precarpathian National University, 57 Shevchenko Str., Ivano-Frankivsk, 76018 Ukraine.

E-mail: tetiana.mykytyn@pnu.edu.ua, dolynko.nelja@gmail.com, natalja14belowa@gmail.com.

Received: 17.11.2020; revised: 15.12.2020.

Долинко Неля, Микитин Тетяна, Бєлова Наталя. Алкогольна інтоксикація та їі вплив на перебіг сперматогенезу щурів-самців. Журнал Прикарпатського університету імені Василя Стефаника, 7 (4) (2020), 46-52.

Проведено морфометричний та функціональний аналіз статевих клітин в гістологічних мікропрепаратах і еякуляті щурів-самців контрольної групи на 7-у, 14-у, 21-у і 28-у добу алкоголізації дослідних тварин. Встановлено, що тривале вживання етанолу знижує резистентність до його дії кдітин сперматогенного епітелію, які знаходяться на різних стадіях розвитку, що проявляється гальмуванням сперматогенезу з редукцією кількості сперматоцитів і сперматид, а в еякуляті зниженням концентрації сперматозоїдів із збільшенням числа їхніх патологічних форм. Проведені дослідження показують, що зі збільшенням терміну алкоголізації у яєчках дослідних тварин спостерігається набряк інтерстиційної сполучної тканини та десквамація частина клітин сперматогенного епітелію. Середній діаметр звивистих сім'яних трубочок зменшується і становить $(221,17 \pm 2,44)$ мкм проти $(241,12 \pm 2,31)$ мкм у контрольної групи тварин. Спостерігається редукція шарів клітин сперматогенного епітелію з масивним їх злущенням у просвіт трубочок.

За цих умов значні зміни виявляються у кінезисграмі сперматозоїдів. Зокрема, концентрація сперматозоїдів в еякуляті знижується до $(56,20 \pm 2,30)$ млн / мл проти $(67,50 \pm 3,60)$ млн / мл, кількість морфологічно нормальних сперматозоїдів - до 57,70\% проти 75,52\%, кількість живих сперматозоїдів до 61,75\% проти 79,36\%, кількість сперматозоїдів з прогресивним рухом - до 35,31\% проти 55,62\% у контролі. Зміни з боку морфологічної будови сперматозоїдів показують, що найбільш чутливою до дії етанолу є головка сперматозоїдів, що проявдяється іï фрагментацією та лізисом акросомальної ділянки. Віддалені терміни експерименту характеризуються значним рівнем аглютинації сперматозоїдів, деформацією основної та проміжної частини джгутиків 3 вираженим цитоплазматичним надлишком, що негативно впливає на їхню рухову активність.

Кдючові слова: сперматогенний епітелій, алкогольна інтоксикація, резистентність. 